\title{
Global Values Locally Transformed
}

The IWMA in the German States 1864-1872/76

\author{
Jürgen Schmidt
}

As in other parts of "the Continent", the International Working Men's Association (IWMA) was in no way a mass movement in the German states in the 1860 s. Indeed, starting with its very organizational model, it seemed that, at first glance, the German labour movement was in danger of reverting to its pre1848 beginnings when secret societies set the tone. In February 1865 , in a letter to Ludwig Kugelmann, Karl Marx suggested to build - according to the French model - local "societies" as starting points for agitation, "no matter how many members are on site". Due to (Prussian) association laws, direct membership to the International Workingmen's Association (IWMA) was not possible for organizations. So these very small organizational nucleuses - for example in Berlin the section only had less than ten members - gave the impression of clandestine, insignificant sects. Although the two major political currents of the labour movement, Ferdinand Lassalle's General German Workers' Association (Allgemeiner Deutscher Arbeiterverein ADAv) and, until the mid-186os, the still liberal oriented and dominated Federation of German Workers' Associations (Vereinstag deutscher Arbeitervereine VDAV), only had about 4,000 to 5,000 and 17,000 members respectively, these organizations appeared to be mass movements compared with the International Working Men's Association. ${ }^{1}$

In such conditions, how could the ideas of the IWMA become influential? How could global values become part of a larger movement within a national frame? First of all, the international organization did not develop into a closed cast; on the contrary the very few members of the IWMA joined other (labour)

1 K. Marx to L. Kugelmann, 23 February 1865, in Karl Marx/Friedrich Engels, Werke, 43 vols (Berlin/GDR, 1956-1990), vol. XXXI, p. 455; Karl Marx, "The Fourth Annual report on the General Council of the IWMA" (The Times, 9 September 1868), in Karl Marx/Friedrich Engels: Gesamtausgabe, 114 vols in IV sections (Berlin, 1975ff.), vol. I/21, p. 85 (hereafter $M E G A$ ); see in general Jürgen Herres: "Einführung", in $M E G A \mathrm{I} / 21, \mathrm{pp} .1125^{-1228}$, 1139ff. and Svetlana Gavril'cenko et al., "Einführung", in $M E G A$ III/13, pp. 641-677, 67of.; see also for association laws in Prussia Herres, "Einführung", p. 1144. For the number of members see as overview Thomas Welskopp, Das Banner der Brüderlichkeit: Die deutsche Sozialdemokratie vom Vormärz bis zum Sozialistengesetz (Bonn, 200o), pp. 39-43. See also fn. 35 of this chapter.

(C) JÜRGEN SCHMIDT, 2018 | DOI 10.1163/9789004335462_009

This is an open access chapter distributed under the terms of the prevailing CC-BY-NC License 
associations. They were marching towards a civil-societal orientated associational model. They made use of the public sphere, tried to convince workers with arguments and actions of the validity of their international approach. This was the first basic pillar. The second basic pillar that the IWMA could win influence within the German states, was its transnational roots and connections. The article will analyse in its central chapter the forms of circulation of ideas and practices and how the ideas of the IWMA (emancipation, participation, solidarity) were adapted to local surroundings and milieus. But first of all some additional factors which helped establish the IWMA's values and shaped its transnationality have to be emphasized, too.

\section{Transnational Migration, Private Networking and Individual Protagonists}

The IWMA in Germany did not start from scratch. Not only the two aforementioned workers' organizations already existed, the formation of the IWMA with its transnational and international character was facilitated by four other factors. First, in the pre-1848 years, labour migration and political exile were important for the first German labour organizations. German journeymen followed well-known routes which led them to France, Great Britain, the Habsburg Monarchy and Switzerland. Abroad, they met political refugees from Germany, came in contact with political ideas of nationalism as well as socialism, democracy and republicanism. ${ }^{2}$ Organizational models as well as mobilization processes could be learned. In France, in the 1830s, the German socialist "League of the Outlaws" (Bund der Geächteten) adopted the pattern of organization of the French "Society for Human Rights" (Gesellschaft der Menschenrechte). ${ }^{3}$ From British Chartism one could learn what impact the organization of broad public meetings could have. After 1848, these centres of migration and exile - especially Paris and London - lost some of their influence on the development of German workers' organizations. But

2 Wolfgang Schieder, Anfänge der deutschen Arbeiterbewegung: Die Auslandsvereine im Jahrzehnt nach der Julirevolution von 1830 (Stuttgart, 1963); see Sigrid Wadauer, "Paris im Unterwegs-Sein und Schreiben von Handwerksgesellen”, in Mareike König (ed.), Deutsche Handwerker, Arbeiter und Dienstmädchen in Paris: Eine vergessene Migration im 19.Jahrhundert (München, 2003), pp. 49-67, 53f.

3 See the source in Verein für Frankfurter Arbeitergeschichte e.V. (ed.), Frankfurter Arbeiterbewegung in Dokumenten 1832-1933. Volume 1: Vom Hambacher Fest bis zum Ersten Weltkrieg 1832-1914. Arranged by Judit Pàkh (Frankfurt/Main, 1994), p. 48. 
the ideas and traditions survived. Individuals remained abroad and could connect their activities with newcomers - for example, in London in the late $1850 \mathrm{~s}$ in the "Communist Working Men's Education Association" (Communistischer Arbeiterbildungsverein, CABV). ${ }^{4}$ All in all, the foundation of the IWMA in London in September 1864 was deeply rooted in a long tradition of international contexts in places of exile.

Second, cross-border contacts became essential to the German branch of the IWMA, because its coordination centre was in Geneva. In the 186os, Johann Philipp Becker was in Geneva the central figure for the German IWMA. Becker was an activist of the 1848 revolution in Germany who became a socialist. ${ }^{5} \mathrm{He}$ was the organizer of the new association. His section founded in Geneva at the end of 1864 was the first branch of the IWMA on the Continent. He built a dense network of correspondence. By December 1871, the number of letters written by Becker for the IWMA reached 4,281. Becker remained in contact with "more than 500 organizations and people in about 170 places in Europe and the USA"; about one third of this network was situated in the different German states. ${ }^{6}$ Becker was also the propagandist of the idea of internationalism. Karl Marx was impressed by Becker, "whose propaganda fever sometimes elopes with his head". ${ }^{7}$ Especially with the foundation of the monthly journal Der Vorbote (The Herald) in January 1866 he widened the spacial scope of the readership. They could read news about the development of the IWMA and strike activities from all over Europe and the USA. The Central Committee of the group of German speaking sections was able to distribute 1,500 copies of the journal from the end of 1868 onward. ${ }^{8}$ In addition, a functioning distribution system

4 Christine Lattek, Revolutionary Refugees: German Socialism in Britain, 1840-186o (London [etc.], 2006), pp. 174, 199ff.

5 Roger Morgan, The German Social Democrats and the First International 1864-1872 (Cambridge, 1965), pp. 63-96; see also Hans-Werner Hahn (ed.), Johann Philipp Becker: Radikaldemokrat - Revolutionsgeneral - Pionier der Arbeiterbewegung (Stuttgart, 1999) (especially the chapter by Daisy E. Devreese: “Ein seltener Mann'. Johann Philipp Becker und die Internationale Arbeiter-Association", pp. 113-128).

6 Rolf Dlubek, "Die Korrespondenz Johann Philipp Beckers als Präsident der Sektionsgruppe deutscher Sprache der Internationalen Arbeiterassoziation", in Jürgen Herres/Manfred Neuhaus (eds), Politische Netzwerke durch Briefkommunikation: Briefkultur der politischen Oppositionsbewegungen und frühen Arbeiterbewegungen im 19. Jahrhundert (Berlin, 2002), pp. 117-176, 121-125.

7 Karl Marx, "Confidentielle Mittheilung" an den Braunschweiger Ausschuss der SDAP, March 1870, in MEGA I/21 pp. 220-227, 223 ("dessen Propagandaeifer zuweilen mit seinem Kopf durchbrennt").

8 Dlubek, “Korrespondenz", p. 124. 
for information in general was built, so that it was in August 1870 possible to smuggle 15,000 copies of the address of the General Council of the IWMA on the Franco-German war to Germany and to France. ${ }^{9}$ Becker's network was feasible and able to work even under pressure. And so, these activities created an imagined unity of workers beyond the nation state. The rather abstract aim and purpose of the First International, that "the emancipation of the working classes must be conquered by the working classes themselves", ${ }^{10}$ became "real" and vivid through narrating the development of the IWMA in the world.

But, third, transnationality needed spearheads and bridgeheads in the German states, too. Wilhelm Liebknecht and August Bebel, Berlin and Leipzig, became central contact points. Liebknecht, who was seventeen years younger than Becker, also participated in the 1848 revolution. After the revolution Liebknecht went via Switzerland and France in 1850 to London into exile. In Britain's capital he came in the same year in contact with Karl Marx and Friedrich Engels - a life-long connection which was pivotal to Liebknecht's political and economic thinking. This friendship was never free of tensions and misunderstandings. But Engels had to admit that Liebknecht - after his return to Prussia, following an amnesty of political refugees - was the "only reliable connection [...] in Germany" the IWMA had." In Berlin and Leipzig Liebknecht was able to convince members of two existing labour organizations ADAV and VDAV of the relevance of socialist internationalism. However, in the fragmented, small labour movement in Berlin, full of rivalries between different individuals and political opinions, it was very difficult to find support and to create a basis for the IWMA. ${ }^{12}$ Marx and Engels reacted angryily at the little progress the association made. ${ }^{13}$

In 1865 , Liebknecht was expelled from Berlin by the Prussian authorities and moved to Leipzig in Saxony. Leipzig became in the long run the place where Liebknecht had his biggest success. There, he was able to develop and

9 J.G. Eccarius to K. Marx, 24 August 1870, in MEGA I/21, p. 1600.

10 Provisional Rules, September/October 1864, in MEGA I/20, pp. 13-15; in German language in Institut für Marxismus-Leninismus beim $\mathrm{zK}$ der SED/Institut für MarxismusLeninismus beim zK der KPdSU (eds), Die I. Internationale in Deutschland (1864-1872): Dokumente und Materialien (Berlin/DDR, 1964), pp. 13-16.

11 F. Engels to K. Marx, 7 August 1865, in MEGA III/13, pp. 521f. For Liebknecht see Wolfgang Schröder, Wilhelm Liebknecht: Soldat der Revolution, Parteiführer, Parlamentarier (Berlin, 2010).

12 Lothar Petry, Die Erste Internationale in der Berliner Arbeiterbewegung (Erlangen, 1975).

13 See Liebknecht's response: W. Liebknecht to F. Engels, 30 August 1865, in Wilhelm Liebknecht, Briefwechsel mit Karl Marx und Friedrich Engels, edited by Georg Eckert (The Hague, 1963), p. 62. 
organize a labour organization which followed the rules and statutes of the IWMA in Germany. He arrived in Leipzig in August 1865. "Things are better" than they occurred, he let Karl Marx and Johann Philipp Becker know: "Until now I only have twelve members [...] but these new members incorporate the entire board of the 500-member-strong workers' education association and other influential democrats". ${ }^{14}$ Here indeed Liebknecht did not exaggerate the development of the movement, as he found in August Bebel an important follower of his ideas.

Liebknecht met Bebel at a time when Bebel had already made his first steps towards socialist attitudes. Until 1865, Bebel followed liberal ideas of self-help and upward social mobility by saving, education and good work - ideals that were prominent and dominant in the VDAV. But, due to, first, his experience that from a certain point on individual advancement could stop and, second, to his failure at mediating a harsh strike conflict in Leipzig, Bebel was in a period of re-orientation. Liebknecht was impressed that a craftsman like Bebel could make such a political career in the VDAV - not only at the local, but at the national level. With Bebel and other members of the VDAV as followers of the IWMA, Liebknecht had made a big contribution to the IWMA because the association now had the possibility to win a mass movement (in relative terms compared with the very small sections). ${ }^{15}$

This was finally realized at the Nuremberg meeting of the VDAV in September 1868 when the left wing part of this workers' association decided to adopt the statutes of the IWMA. "The social question is a global question", stated the writer Robert Schweichel at the meeting to convince the delegates about a future program. The program of the IWMA would be the best, "because it expresses the demands of the workers with sharpness and clarity and because one requires a flag for the entire working class in the whole civilized world". ${ }^{16}$ The IWMA now had an organizational basis within Germany and became part of the social-democratic movement. A year later, when the SDAP was founded as a successor of the internationalist branch of the VDAV, it was, however, also expressed clearly by August Bebel that a direct and formal participation

14 W. Liebknecht to Karl Marx, 14 April 1866, W. Liebknecht to J.P. Becker, 8 February 1866, quoted in Schröder, Liebknecht, pp. $157 \mathrm{ff}$.

15 Jürgen Schmidt, August Bebel: Kaiser der Arbeiter. Eine Biografie (Zürich, 2013), pp. 67ff.; Wolfgang Schröder, Leipzig - Die Wiege der deutschen Arbeiterbewegung: Wurzeln und Werden des Arbeiterbildungsvereins 1848/49-1878/81. Mit einer Dokumentation der Tätigkeitsberichte (Berlin, 2010), pp. 140-146.

16 Bericht über den Fünften Vereinstag der Deutschen Arbeitervereine, in Dieter Dowe (ed.), Berichte über die Verhandlungen der Vereinstage deutscher Arbeitervereine 1863-1869 (Berlin [etc.], 1980), pp. [150]ff.; Schröder, Leipzig, pp. 179-197. 
of the new SDAP in the IWMA was not possible due to German association laws. The IWMA now had stable contact partners and partner organizations within the German states, but direct membership was still only possible for individuals and so dependent on personal engagement for the internationalist idea. $^{17}$

Finally, traditions of socialist internationalist thinking can be traced back to the pre-revolutionary years 1848/49. But Friedrich Engels' work The Condition of the Working Class in England, published in 1845 in Germany, and the Communist Manifesto of 1847-8 were not present any more. ${ }^{18}$ Marx and Engels were forgotten voices in Germany. The fact that Marx and Engels did not stand in the first row of known intellectuals in Germany before the mid-186os, does not mean of course that we should neglect their role in an article describing the situation of the IWMA in Germany. First of all, from the organizational perspective Marx took on, within the IWMA's General Council in London, the role of the "corresponding secretary" for the German labour movement. ${ }^{19}$ In this position he was "responsible" for reporting to the General Council about the development of the IWMA in Germany. But with regard to the concrete organizational work in the German speaking countries, he never played as central a role as the local organizers Becker, Liebknecht and Bebel - even though the section of Solingen in the Rhineland asked Marx to send a portrait of him to decorate their meeting place. ${ }^{20}$

Marx' role (and that of Engels) was that of a provider of ideas and advice abroad. He was mainly involved in the formulation of the statutes of the IWMA which were read and discussed in Germany - and in 1869 became part of the SDAP. In addition, in Johann Philipp Becker's Der Vorbote Marx' Das Kapital was promoted again and again as required reading for the workers to understand the economic system in which they were living. The influence of this should, however, not be overestimated. Even August Bebel never got very familiar with this text and for most workers it remained a closed book. About 700 copies had been sold by $1870 .{ }^{21}$ But especially Bebel and Liebknecht were able to popularize the main ideas of Marx and thus Marx became the reference point of the early German labour movement: "It is necessary that

\footnotetext{
17 For the relations between the IWMA and Lassalle's ADAV see Morgan, Social Democrats, pp. 34-62, 165-167; MEGA I/21, pp. 1458f.

18 W. Liebknecht to K. Marx, 3 May 1865, in Die I. Internationale in Deutschland, p. 56.

19 Julius Braunthal, Geschichte der Internationale, 3 vols. Third Edition (Berlin [etc.], 1978), vol. I, p. 114; Herres, "Einführung", pp. 1162-1169.

20 Section Solingen to K. Marx, 6 April 1869, in Die I. Internationale in Deutschland, p. 325.

21 Der Vorbote, Nr. 4ff., April 1867ff.; Herres, “Einführung”, p. 1210.
} 
the I. W. [M.] A. is represented there [in Nuremberg 1868] either by you or by [Johann Georg] Eccarius; but if ever possible, by you, because no one else has the same authority", Liebknecht wrote to Marx. ${ }^{22}$ And Bebel wanted to impress the leading figure in London with his self-confident prognosis that at the Nuremberg meeting "success is indubitable". 23

\section{Values, Ideas and Actions of the IWMA in Germany: Chances and Boundaries}

Social movements would never become social movements if they depended on individual leading figures and their ideas alone. Linkage of very different individual, social, economic, cultural and political conditions and requirements was needed, that as result in a cross-section of all these factors a movement such as the labour movement could emerge. Structural changes and developments like industrialization and urbanization, the expansion of wage labour, the rise of ideas and language of class, new forms of working class actions, the growth of cultural paradigms specific to workers and formed by them, have to be considered, but cannot, however, be discussed and described here at length. But it is noteworthy to mention that people like Becker, Liebknecht, Bebel, Marx and Engels were influential due to their ability to build communication networks of strategic importance. Therefore both were needed: the individual leading figures and their ideas on the one hand, and the above-mentioned changes and structures and out of them resulting experiences as sounding board, as resonant cavity, on the other hand. Ideas, structures and experience had to be to a certain degree in accordance with each other to build the basis of a movement and its organizational framework. If we take this model as starting point, it is possible to describe the success and boundaries of values and actions of the IWMA in Germany.

Three points will illustrate the success of transferring international and global values. First, the idea of emancipation - so prominent in the IWMA founding documents - could be transformed easily at the local level because in practice it meant building from the associational culture of the nineteenth century and, by doing so, emancipating from bourgeois patronization. The craftsmen and workers were no longer satisfied with only partial integration but without real participation on behalf of the Liberals or being mere subjects within patriarchal welfare concepts of the Conservatives. August Bebel, who came from the

22 W. Liebknecht to K. Marx, 23 July 1868, in MEGA I/21, p. 1880.

23 Schmidt, August Bebel, pp. 93, 97. 
liberal association movement, wrote to Moritz Müller in 1868 "that the associations should elect their leaders from their own ranks; doctors and professors were not suited as leaders - we know that from our own experience". ${ }^{24}$ This was the articulation of a self-confident and independent voice of workers' emancipation. And since in the IWMA as in the German labour movement the association remained the organizational model, transnational dissemination was - despite disputes on questions with regard to content - easy to manage. The delegates of the association's conventions and international congresses discussed questions of their organizational statutes with admirable matter-of-factness. ${ }^{25}$

But these deliberative processes required special skills. This meant not only that the delegates who were sent to the IWMA meetings were well educated and often had an academic background, it meant also that in the local organizations of the IWMA and German labour movement a lot of workers were excluded from the emancipation and participation process for which the IWMA was standing. For example, Wilhelm Liebknecht argued at a congress in 1875: "The word worker definitely does not have an exclusive character. Work is the activity of mankind." ${ }^{26}$ However, this inclusive approach was conflictual in practice. Numerous values and forms of contact came from the world of male-dominated skilled trades and work. These spaces thus remained foreign and closed to women, farm workers and unskilled workers. ${ }^{27}$ So, all in all, emancipation was a value which the local branches and individual members were familiar with and, as such, it was a driving force for organizational efforts. However, it was practiced only by selected groups of workers.

Second, the circulation and transformation of international and global ideas to the local basis and to local organizations were facilitated by the use of and intimacy with the public sphere. It was to a large extent a copy of the bourgeois public sphere with its newspapers, journals and associations. The Vorbote but also other workers' press - helped circulate ideas of internationalism. But meetings in clubs also played an important role. For example, a member of

24 A. Bebel to M. Müller, 16 July 1868, in Ilse Fischer (ed.), August Bebel und der Verband Deutscher Arbeitervereine 1867/68: Brieftagebuch und Dokumente (Bonn, 1994), p. 267.

$25 C f$. the sources in Ilse Fischer, August Bebel; Die I. Internationale in Deutschland; Braunthal, Geschichte; Henryk Katz, The Emancipation of Labor: A History of the First International (New York [etc.], 1992).

26 Protokoll des Vereinigungs-Congresses der Sozialdemokraten Deutschlands abgehalten zu Gotha, (Leipzig, 1875, reprint 1976), pp. 35f.

27 See Jürgen Schmidt, "Zivilgesellschaft, sozioökonomische Spannungslinien und sozialmoralisches Milieu. Arbeiterbewegung und Arbeiterparteien in Deutschland von 186o bis 1914", Archiv für Sozialgeschichte, 53 (2013), pp. 19-46, pp. 31f. 
the ADAV described how he was going to promote the international idea. In September 1865, Carl Friedrich Dültgen wrote to Becker that he would explain in the next meeting in Solingen (Rhineland) that "it is only possible to achieve something through a general fraternization and not through an isolated position of Germany". ${ }^{28}$ In addition, through public outdoor meetings the German social democratic movement as representative of the IWMA established new models of participation beyond the bourgeois public sphere. In June 1866, Liebknecht reported to Marx that he had given in Chemnitz a speech in front around 2,000 workers about reducing working hours, organizing the labour movement and the IWMA: "If I had had membership cards with me, I could have won a dozen good active members and one thousand indifferent ones. But yet nothing is lost; I will return there". ${ }^{29}$

Within this network of words, texts and discussions in the public sphere, metaphors could also circulate. Of course, it could have been common to use the word "Rosenwasser" (rose water) in the 1860s and therefore have been by accident that August Bebel in his first long programmatic text "Unsere Ziele" (Our Aims) used this word. But, the context in which Bebel used the term was exactly the same as in the first programmatic article of "Der Vorbote" written by Becker. In both paragraphs, both authors emphasized that the way to come to power would be a peaceful one. However, if the resistance of the opponents was brutal and violent, the labour movement would not merely "sprinkle rose water". ${ }^{30}$ Creating a semantic field of internationalism not only facilitated the move of images, it was important because it helped build a consciousness of shared inequalities and solidarity across borders.

Third, one of the most effective means to construct a sense and consciousness of international solidarity was through the support of comrades on strike $^{31}$ and the adoption of international trade union models. In Der Vorbote one can find again and again financial support for workers on strike in different countries - mainly in Britain, France and Switzerland. Sometimes this aid was rather symbolic with regard to the amount of money, sometimes it was financial relief that made the situation for the strikers a bit easier. Instead of doing

28 C.F. Dültgen to J.P. Becker, 24 September 1865, in Die I. Internationale in Deutschland, p. 79.

29 W. Liebknecht to K. Marx, 5 June 1866, in ibid, p. 124.

$30 \quad$ Der Vorbote 1 (1866), Nr. 1, January 1866, p. 8; August Bebel, Unsere Ziele (Leipzig, 1872), p. 16 (in addition, in the previous paragraph Bebel emphasized that the "organization must be international because our conditions are not symptoms of individual nations but belong to all civilized people").

31 For a general overview see Knud Knudsen, "The Strike History of the First International", in Frits van Holthoon/Marcel van der Linden (eds), Internationalism in the Labour Movement 1830-1940, 2 vols (Leiden [etc.], 1988), I, pp. 304-322. 
a quantitative analysis of this transnational (financial) exchange, I will use a single case for a qualitative approach and illustrate with the following quotation how a narrative of transnational solidarity was constructed:

Two days ago the Central Committee of the Sections of German Language here [in Geneva] got news and further information about the strike of 1,400 coal miners in Essen which started with all right. Yesterday evening the Central Committee of the united Geneva Sections decided with one consent, following the demand of Becker - although money was scarce due the pressure of the strike in spring - to send immediately 200 Swiss Francs as a small gesture of fraternal support. Our other sections as well as all workers' clubs will not sit back where it is essential to transform solidarity into practice and to show that workers of all countries belong to the same family. The address is: Lakowsky, miner, Limbeckerstraße, 75, 1 staircase, in Essen. ${ }^{32}$

First of all, the report emphasized that the strike was justified. This meant that the conflict was not the result of a selfish, undisciplined and unreasonable behaviour. Instead, the strike was legitimized - as stated in a later part of the report - because of a severe fight between workers and businessmen about the withdrawal of wage reductions. This assessment of the strike as part of a class struggle helped generalize its meaning for workers in other parts of Europe. Secondly, the term "family" evokes strong ties. Support would not be received by totally unknown people, but by people to whom one was closely related. It was not (only) the abstract, economic-social category of class which should create solidarity but a kind of private, personal bonding. Thirdly, this text made a strong argument by underlining that this support was the main method to "transform solidarity into practice". The fine idea of international solidarity was without consequences, if it remained on the metaphoric level. Words had to be followed by actions if one wanted to surmount national borders. Finally, this paragraph tried to build trust, and the text's success was totally dependent on trust. The report suggested support only after the Central Committee received "further information" and - as mentioned - after it was proved that the strike was necessary. It was the authority of the Central Committee with its transnational connections and the individual Johann Becker, that made the information and the contact person reliable. Only with this expertise and competence was it possible for readers of this article to send 
money to an unknown miner named "Lakowsky", living in Essen in "Limbeckerstraße 75 " on the first floor.

The formation of "International Trade Associations" (Internationale Gewerksgenossenschaften) in Germany can be described as a transnational learning process, too. The German organizations were more or less direct outcomes of the decisions made at the Geneva IWMA congress in 1866, when the building of such unions was suggested. The statutes August Bebel developed, were similar to the Geneva suggestions. In addition, Bebel convened in October 1868 a workers' meeting where Liebknecht gave a presentation on the topic and in a resolution formulated that it would be necessary that the foundation should be "in accordance with the model of the English trade unions". On the other side, Bebel frankly admitted that the term "international" was some kind of a fraud because "we could only expect to integrate the German speaking countries into our organization. The main idea of this name was to express a tendency" in this movement. ${ }^{33}$ The "tendency" Bebel wanted to express, was to secure a broader base for his political ambitions in order to found a social democratic, "left-wing" labour movement and to demonstrate the relationship with the international movement in Europe.

In practice, the use of the term "international" in the trade union associations was more a strategic approach, but at least it could be utilized as a flag to facilitate the perception of the social and political question of the working class as a transnational phenomenon. The same is true of the political dimension of the IWMA in Germany. Although Bebel, Liebknecht and Johann Baptist von Schweitzer, president of the Lassallean ADAV since 1867, profited from the organizational background of internationalism, for all of them "the building up of a national organization came first". Bebel definitely declared at the founding congress of the SDAP in Eisenach 1869: "At any rate, the social democratic party in Germany has first to constitute itself, because beside international organizations national organizations are essential; and those without these would be a mere shadow". In general, one can argue that internationalism was a kind of vehicle to build paradigms for modernizing the German nation. Global values of humanity, fraternity and civility, vivid in international social-democratic organizations, could help transform nations in peaceful partnership. ${ }^{34}$

August Bebel, Aus meinem Leben, 3 parts (Stuttgart, 1910-1914), I, p. 207; Welskopp, Banner, pp. 69off.

34 Morgan, German Social Democrats, p. 174; Protokoll über die Verhandlungen des Allgemeinen Deutschen sozial-demokratischen Arbeiterkongresses zu Eisenach (Leipzig, 1869, reprint 1976), p. 73; see also Welskopp, Banner, pp. 534ff. (with regard to August Bebel's vision of a future system of nation states). As general topic of the IWMA see Michael Forman, 
But these successes have to be reassessed. First, at a quantitative level the number of members remained relatively small. Since neither the VDAV nor the ADAV could become direct members of the IWMA, it depended on the willingness of individuals to join the IWMA. Between 1867 and 1869 the number of members only rose from 150 to 250 . After the foundation of the SDAP in 1869 , the IWMA in Germany did not exceed a few thousand members. ${ }^{35}$ While this number sounds at least impressive, the reality looked very sobering. In a letter to Marx, Liebknecht saw very good chances that at the Nuremberg conference 1868 the VDAV would "join the Int. A. A. [i.e.Internationale Arbeiter-Association]. But we are unable to pay much or even anything besides what we have to pay." Until the end of 1869 no payments by German workers' clubs reached Becker or the General Council at all. ${ }^{36}$ The situation could have been made even worse when local members asked the central organization in London for support without results. The reaction to a strike of German miners in Lower Silesia in 1869-70 was harsh:"In Answer to an application from the executive of the Social Democratic Party of Germany for loans for the miners of Waldenburg, now on Strike, the German Secretary was instructed to reply that it was impossible at present to do anything, \& a general instruction was given to the secretaries to state in their correspondence that there was no prospect [of] obtaining pecuniary aid in London under existing circumstances." ${ }^{37}$ Disappointment and doubts about the internationalist approach could be the result. ${ }^{38}$

This weakness, finally, could be seen with regard to its failure to forge a sword against dominant nationalism. During the 1866 Prussian-Austrian war the IWMA in the German states faced a decline in membership. But the

Nationalism and the International Labor Movement: The Idea of the Nation in Socialist and Anarchist Theory (University Park, 1998), pp. 19-65.

35 Franz Mehring even estimated that the number of members was not much higher than a thousand (quoted in Braunthal, Geschichte, p. 125). The higher figures - for $1870-$ mentioned by Musto would presuppose that all members of the Social Democratic Workers' Party at the same time would have been members of the IwMA. This was never the case (Marcello Musto, Workers Unite! The International 150 Years Later (New York [etc.], 2014), pp. 7, 28f., 68).

36 W. Liebknecht to K. Marx, 17 July 1868, in $M E G A$ I/21, p. 1878; M. Quick to J.P. Becker, 29 August 1869, in MEGA I/21, p. 1888f.; F. Engels to Brunswick committee of the SDAP, 28 April 1870, in $M E G A$ I/21, pp. 228ff.; see also Dlubek, "Korrespondenz", p. 128; Herres, "Einführung", pp. 1144f.

37 Meeting of the General Council, 4 January 1870, MEGA I/21, p. 741 (capital letters in the source).

38 On the other side, one should not forget the positive financial aspects of international solidarity. In 1869 for example J.P. Becker estimated the amount of money collected all over Europe for textile workers in Basle in a nine-week strike at 12,00o Swiss Francs. But for a fuller picture, it is also necessary to point to the quantitative weaknesses of the IWMA. 
international movement as a whole was not strong enough to immunize the workers against nationalism. The movement was too small; the idea had tradition neither in the middle nor in the lower classes. In a century of nation states, in the cases of Italy and Germany in a period of nation-state-building, it was impossible to enforce internationalism as a concept and as a mass movement. Internationalism was not self-evident; it was not learned at schools; it was an abstract, intellectual idea which had to be learned and communicated.

\section{Concluding Remark}

The IWMA was confronted by its limitations again during the Franco-German war 1870-1. It could not prevent the war, and the Lassallean ADAV gave its consent to the first war loans; August Bebel and Wilhelm Liebknecht from the SDAP abstained from voting. The second round of war loans in November 1870 was refused by both socialist political currents. In the debate about the loan at the German Reichstag, Bebel gave a masterpiece of parliamentarianism. He declared that Germany would with the annexation of Alsace and Lorraine "trample the right of self-determination of the people by foot". ${ }^{39}$ The harsh and un-Parliamentarian reactions in Parliament against Bebel exposed society's deeply rooted national furore as well as the trials against Bebel, Liebknecht and other party members (see Figures 8.1 and 8.2) showed the willingness of the state to destroy the international movement. The IWMA and its organizers in Germany clearly were detached from this fury and with transnational solidarity and emancipation had alternative models in mind and practiced them. But first of all, their range and influence didn't reach far enough. The first IWMA member sections and clubs did not keep to their small circles, they participated in the public sphere; they were on their way to a civil society orientated association model, but it was only a first step for a small, privileged, interested and educated group of workers. Second, they were children of their time and they were very - perhaps too - realistic. A success for a working-class movement under the predominant conditions and structures of nation states was only possible if it built strong organizations at the national level first. How difficult it has been until today to create a self-evident idea of transnational and international cooperation and solidarity can be seen in the success of antiEU-parties throughout Europe. It is not only an antipathy towards the "bureaucratic monster" in Brussels and towards the Euro, it is also the belief that a national paradigm can secure social standards, defend individual demands and protect from unclear fears better than a shared transnational unity.

See Schmidt, August Bebel, pp. 107-111. 


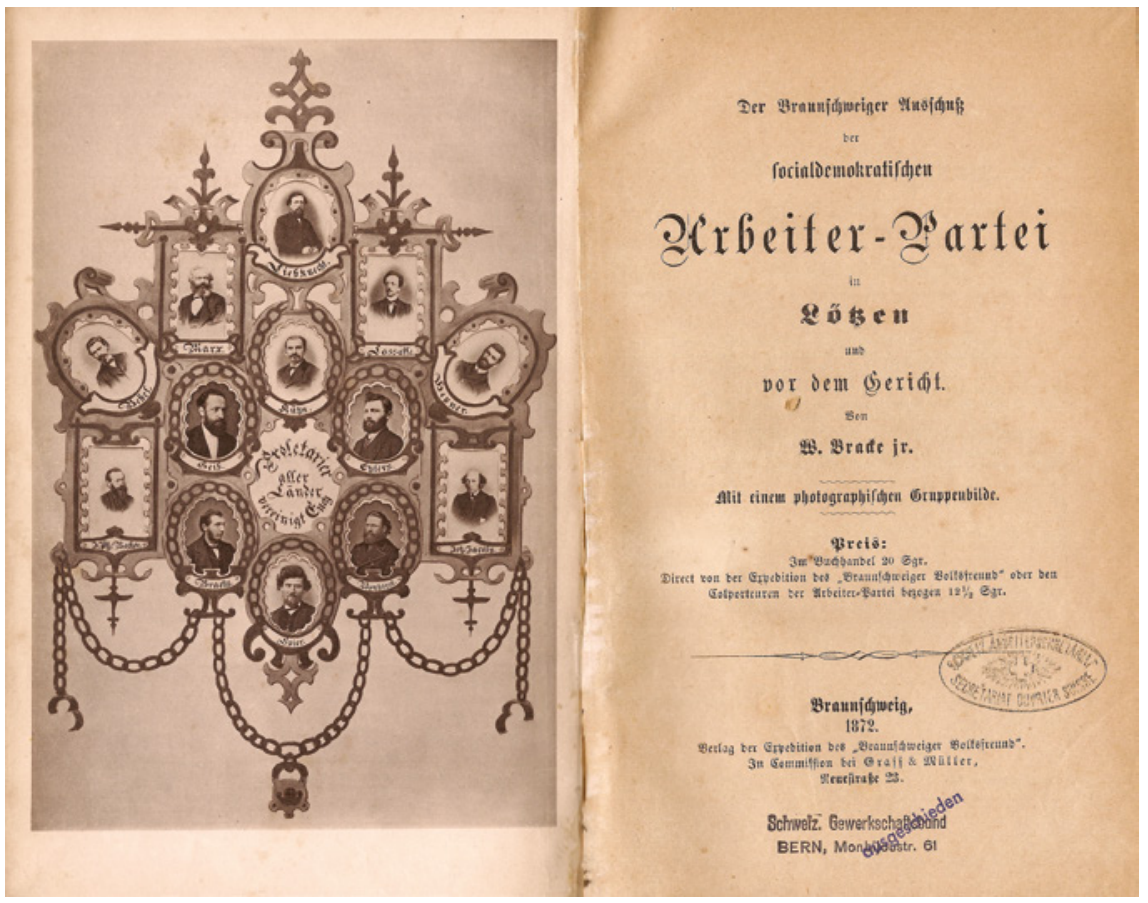

FIGURE 8.1 First pages: Trial of the Social Democrats in Germany, 1872.

Der Braunschweiger Ausschuss der Socialdemokratischen Arbeiterpartei in Lötzen und vor dem Gericht von W Bracke. Mit einem photographischen Gruppenbilde, Braunschweig, 1872 [The Brunswick committee of the Social Democratic Party in Lötzen, outside the court, by W. Bracke. With a photograph of the group, Brunswick, 1872].

PRIVATE COLLECTION OF MICHEL CORDILLOT. 


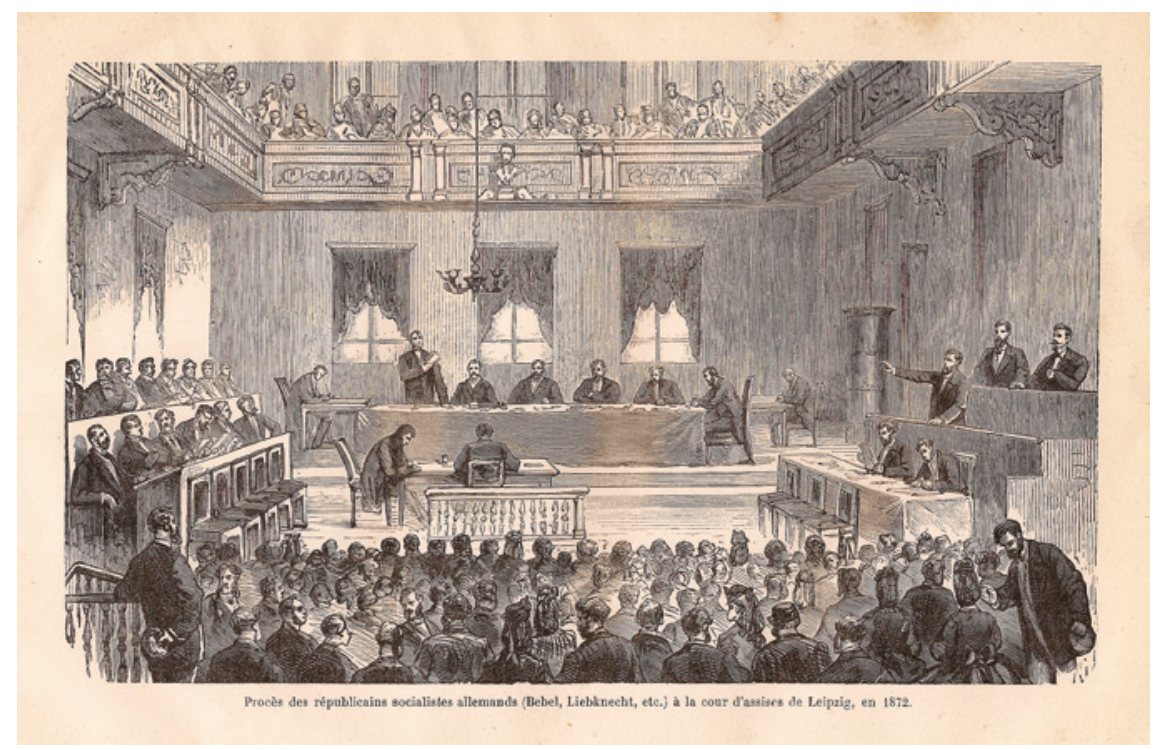

FIGURE 8.2 "Trial of the German socialist republicans (Bebel, Liebknecht, etc.) in the assizes court in Leipzig, in 1872 ".

PRIVATE COLLECTION OF MICHEL CORDILLOT. 